\title{
A Review of Leaf-mining Insects and Control Options for their Management, with Special Reference to Holocacista capensis (Lepidoptera: Heliozelidae) in Vineyards in South Africa
}

\author{
L.A.I. Steyn, H. Geertsema, A.P. Malan, P. Addison*
}

Department of Conservation Ecology and Entomology, Faculty of AgriSciences, Stellenbosch University, Private Bag X1, Matieland 7602, Stellenbosch, South Africa

Date of submission for publication: May 2020

Date of acceptance for publication: August 2020

Key words: Integrated pest management, leaf miner, biological control, grapevine

\begin{abstract}
A leaf-mining pest occurring on commercial varieties of Vitis vinifera in South Africa was investigated due to the presence of cocoons on fruit. The leaf miner, Holocacista capensis, was reported on grapevines in 2012. Since its discovery on commercial grape varieties, control strategies have consisted solely of insecticide applications. Despite the fact that the leaf-mining habit is taxonomically diverse and considered ancient, little is generally known of leaf-mining larvae. A review was conducted in order to better understand the leaf-mining strategy and amalgamate the current knowledge of other leaf-mining insects. The general evolutionary history within the full complement of taxa that display the leaf-mining habit is discussed. The review focuses on lepidopteran leaf-mining pests and discloses the known information associated with the first report and the impact of $\boldsymbol{H}$. capensis in the Western Cape, South Africa. As no control methods have been identified for $H$. capensis in vineyards, various chemical, biological and cultural control strategies adopted for other leaf-mining pests were investigated. Control options, including the use of entomopathogenic nematodes (EPNs), parasitoids, physical and cultural control measures, were considered and are discussed. Alternate control methods are pertinent for the grape-growing industry to avoid the development of the insecticide resistance that is common amongst leaf miners. This review aims to consolidate the available literature and therefore aid in the development of an integrated pest management strategy to effectively control $H$. capensis in infested vineyards in South Africa.
\end{abstract}

\section{INTRODUCTION}

Grapevines in South Africa are host to more than 35 insect pests, with the key pest orders being Hemiptera (mainly shield bugs, scale insects, mealybugs and planthoppers), Coleoptera (beetles) and Lepidoptera (butterflies and moths) (Allsopp et al., 2015), which pose a threat to the industry.

In 2012, an unknown leaf-mining heliozelid was reported, infesting a table grape vineyard in the Western Cape province, South Africa. At the time, the known heliozelid fauna from Africa were limited to three species described in South Africa (Van Nieukerken \& Geertsema, 2015). Subsequent field visits indicated high larval/leaf mine abundances and cocoon casings of the leaf miner on the foliage, stems, trellises and grape bunches in vineyards. In 2015 , the leaf miner was described by Van Nieukerken and Geertsema (2015) as Holocacista capensis Van Nieukerken \& Geertsema (Lepidoptera: Heliozelidae). Since the discovery of $H$. capensis in 2012, a concomitant study by Wang et al. (2015), using gas chromatography-mass spectrometry, identified the sex pheromone (more accurately, a male attractant) of $H$. capensis. Baseline studies to better understand the bio-ecology of $H$. capensis in the Western Cape were conducted by Torrance (2016).

Sustainable, effective control of the leaf miner is pertinent for the grape-growing industry in South Africa to avoid the development of resistance against commonly used insecticides. This review consolidates the available literature regarding the leaf-mining habit, lepidopteran miners as pests, and the effect of the environment on their infestation levels. Management options for leaf miners with regard to chemical control, the use of entomopathogenic nematodes (EPNs), parasitoids and other control measures were considered in the light of possible future control options for $H$. capensis on grapevines in South Africa.

\section{LEAF-MINING INSECTS}

Globally, little is known of leaf-mining insects (Vári, 1961; Auerbach et al., 1995; Lees et al., 2014). Leaf-mining insects are a taxonomically diverse group of endophagous insects and the larvae of leaf-mining taxa are, in most cases, concealed within the plant tissue of their hosts during larval

*Corresponding author: E-mail address: pia@sun.ac.za

Acknowledgements: Financial support for this work was provided by the National Research Foundation (NRF), the South African Table Grape Industry (SATI), and the Technology and Human Resources for Industry Programme (THRIP-TP14062571871). 
development, or at least for part thereof (Hering, 1951; Kirichenko et al., 2018). The duration of the leaf-mining stage varies between species and is not only associated with larval growth, but can also cover the development of pupae and the emergence of adult insects in taxa that pupate within the leaf mine (Connor \& Taverner, 1997).

Despite the fact that the leaf-mining habit is ancient, it continues to be lost and acquired by a number of phytophagous insect lineages (Connor \& Taverner, 1997) and has evolved independently numerous times (Auerbach et al., 1995). The leaf-mining habit is known to occur in at least 57 families within four insect orders, accounting for more than 10000 leaf-mining species (Connor \& Taverner, 1997). The mines originating from the respective orders are classified into specific groups, namely lepidopteronome (Lepidoptera), dipteronome (Diptera), coleopteronome (Coleoptera) and hymenopteronome (Hymenoptera) mines (Hering, 1951).

The geographical distribution of endophagous insects, like leaf miners, is inevitably dependent on the distribution of their larval host plants. In most cases, however, the distribution of a leaf miner is less extensive than that of its host plant (Hering, 1951). Amongst the herbivorous insects, many leaf miners pose a threat to a variety of forest and urban plant species, whilst others are regarded as important pests of agricultural crops and are considered an economically important group globally (Spencer, 1973; Nielsen \& Common, 1991; Digweed et al., 2009).

Over the last decade, an increase in incidents of leafmining insects has attracted the attention of the agricultural and horticultural industries due to their presence in commercial forests, agricultural landscapes and on ornamental plant varieties of high value (Van Nieukerken \& Geertsema, 2015; Kirichenko et al., 2018).

\section{THE LEAF-MINING HABIT}

In the past, the concealed feeding environment of endophagous insects was speculated to provide a competitive advantage when compared to their exophagous counterparts (Hering, 1951; Nielsen \& Common, 1991), and to protect feeding larvae from natural enemies (Hering, 1951; Price et al., 1987). It also provides a buffer against the physical environment (Connor \& Taverner, 1997), and enables the feeding larvae to avoid plant defences (Feeny, 1970) and thus facilitates selective consumption of more nutritious leaf tissue (Cornell, 1989). Price et al. (1987) and Connor and Taverner (1997) reviewed some of these hypotheses amongst various endophagous feeders and arrived at similar conclusions. Connor and Taverner (1997) suggest that the selective advantages inherent to the leaf-mining habit are to facilitate: 1) increased feeding efficiencies, which support some of the hypotheses and findings of Cornell (1989); 2) the avoidance of negative effects associated with disease, should it be present within a population or species, by internally feeding larvae; 3 ) the protection of larvae from the direct and indirect effects of photochemical changes in plant chemistry, for example due to UV radiation; and 4) the reduction of water loss and lessening the risk of desiccation by the presence of a buffered micro-environment within the feeding leaf gallery.

Connor and Taverner (1997) also highlight the disadvantages of the leaf-mining habit. These include: 1) the loss of mobility, which thus cause larvae to be unable to escape parasitoids and predators; this is supported by statements made by Nielsen and Common (1991); 2) decreased species richness within leaf-mining lineages when compared to that of exophagous insects; 3) mortality associated with plant senescence, herbivory and premature abscission of leaves; and 4) reduced fecundity due to the small size of individuals.

From an evolutionary perspective, the disadvantages of the leaf-mining habit outweigh the advantages. The persistence of leaf-mining guilds in various insect orders and environmental niches in the present day, however, proves that, for some taxa, the leaf-mining habit is a feasible means of survival under certain circumstances (Connor \& Taverner, 1997).

\section{LEPIDOPTERAN LEAF MINES}

Apodal or legless lepidopteran leaf-mining larvae (or "serpentine larvae") consume the mesophyll between the upper and lower epidermal layers of a leaf (Stehr, 1992; Bernardo et al., 2015), creating small blotch mines or galleries within the parenchymal tissues of host plants (Hering, 1951). These feeding channels, or cavities, serve as both living and feeding quarters for leaf-mining larvae (Hering, 1951).

The shape of a leaf mine and the presence of voluminous frass often presents a unique feeding pattern within an infested leaf, which can be used as a diagnostic tool for species-specific identification (Hering, 1951; Kirichenko et al., 2018). Mines produced by any leaf-mining insect can be used to determine the order, family and, in many cases, the particular genus (Hering, 1951; Vári, 1961). Lepidopteran hyponomology (the study of mines) often provides a clear and more accurate indication of species identity than comparing fine differences in larval and adult morphology.

\section{LEPIDOPTERAN LEAF-MINING PESTS}

Lepidoptera account for the majority of leaf-mining insects (Kirichenko et al., 2018). As a result, and due to the destructive qualities of the larval life stages of some of the leaf-mining species, these Lepidoptera are considered to be of great economic importance (Nielsen \& Common, 1991). At least 40 lepidopteran families exhibit leaf-mining habits, with considerable variation between species. These lepidopteran leaf miners account for approximately 70\% of all known insect families associated with leaf-mining activities (Connor \& Taverner, 1997; Kirichenko et al., 2018). Within the Lepidoptera, the leaf-mining families of economic importance include the Gelechiidae, major pests in the forestry and agricultural industries (Lee et al., 2009); the Gracillariidae, notorious as invasive leaf-mining pests of woody plants (Kirichenko et al., 2018); and the Heliozelidae, predominantly pests on trees and vines (Davis, 1998). A list of lepidopteran leaf-mining agricultural pests is presented in Table 1.

\section{HELIOZELIDAE - THE "SHIELD BEARERS"}

The Heliozelidae (Lepidoptera: Adeloidea) are a group of widely distributed, cosmopolitan, minute, diurnal microLepidoptera (Davis, 1998; Powell, 2003, Van Nieukerken 


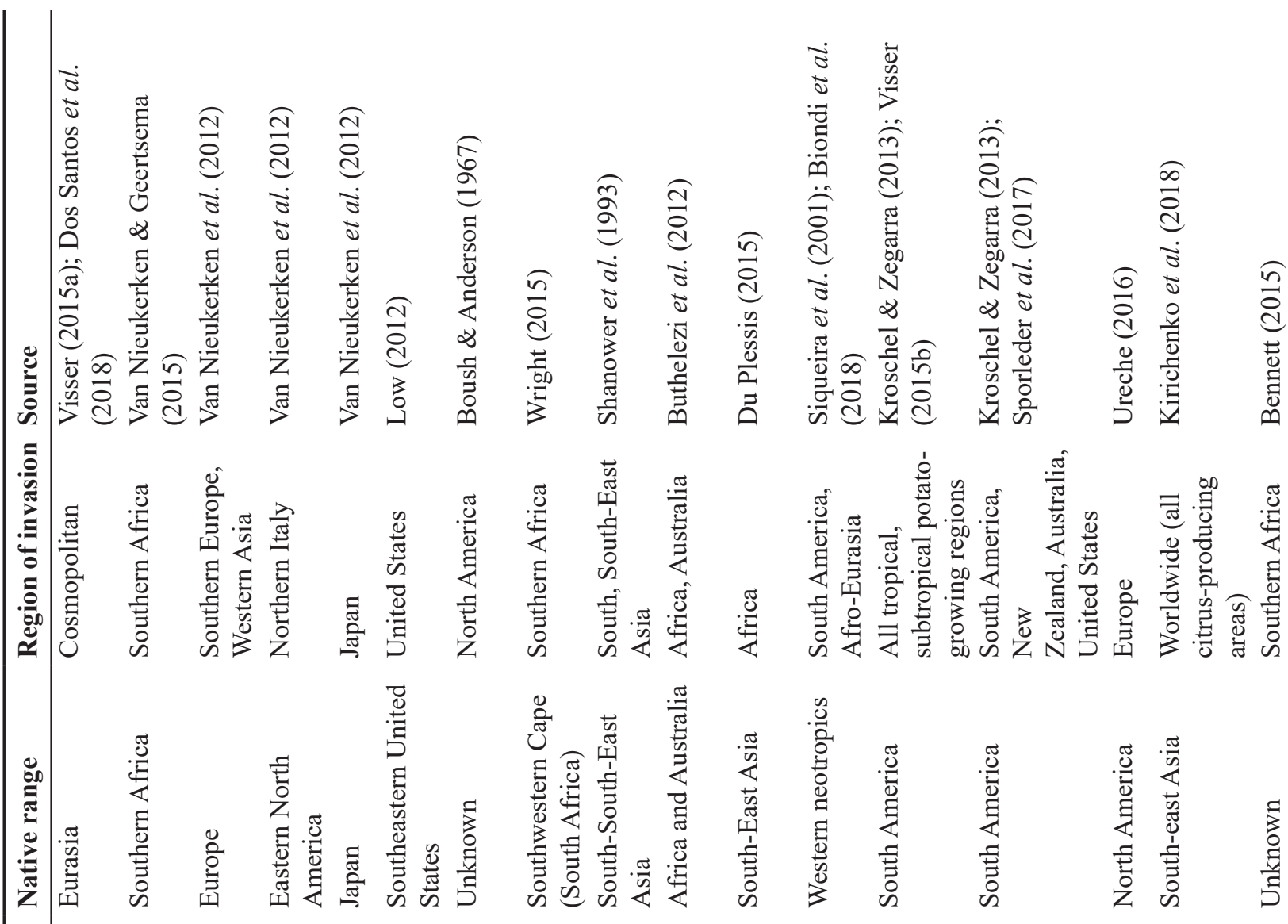

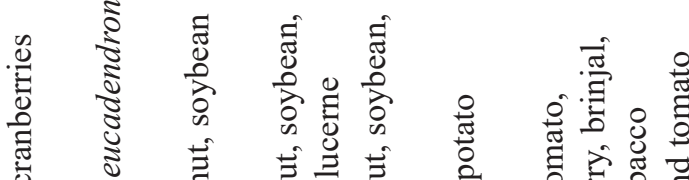

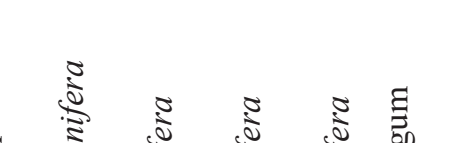

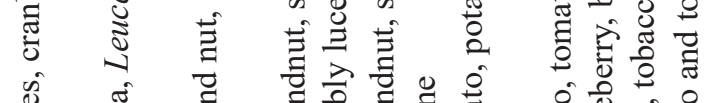

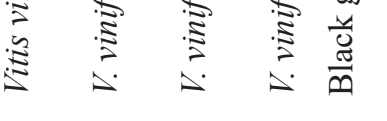

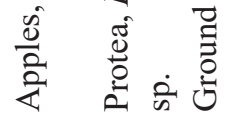

毫亳熟彭

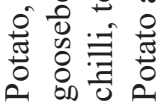

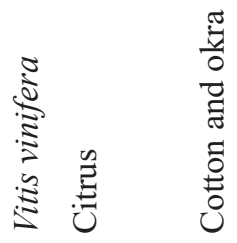

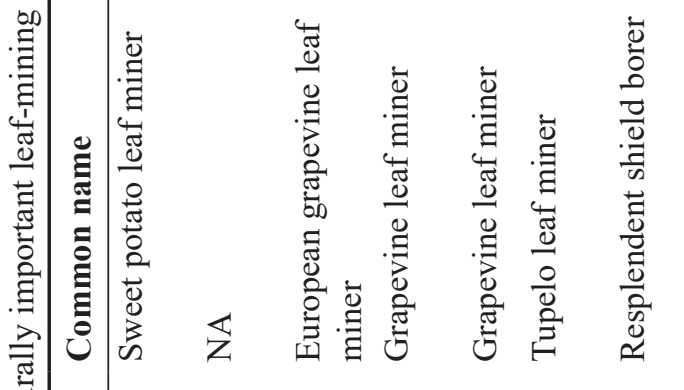

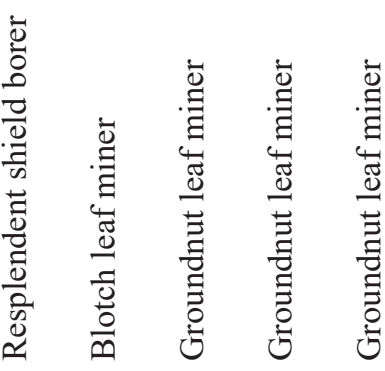

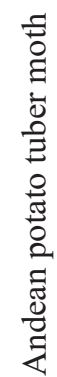

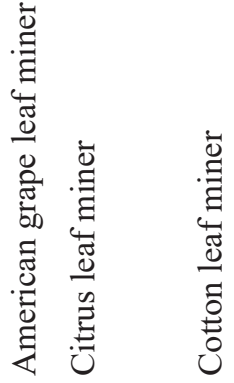
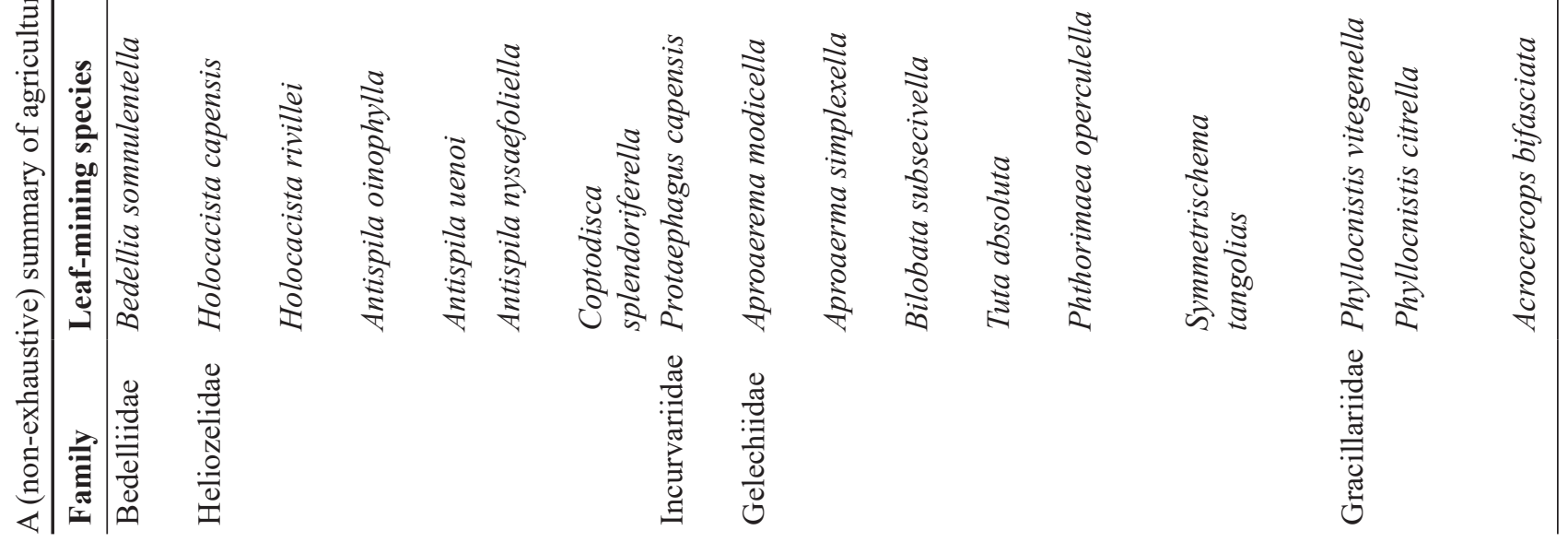
et al., 2011; Regier et al., 2015; Milla et al., 2018), present in all major faunal realms, with no representatives in New Zealand and Antarctica. One hundred and twenty-five described species comprise the Heliozelidae, placed in 12 genera (Van Nieukerken et al., 2011; 2012; Van Nieukerken \& Geertsema, 2015). The family is taxonomically poorly studied, although taxonomic revisions associated with heliozelids have been conducted by Van Nieukerken et al. (2011), Regier et al. (2015), Van Nieukerken and Geertsema (2015) and Milla et al. (2018) (Fig. 1) in recent years.

Heliozelid moths are typically small, with their forewings ranging from $1.7 \mathrm{~mm}$ to $7.0 \mathrm{~mm}$ in length (Regier et al., 2015). Due to their small size, most heliozelids are rarely seen or collected, even when population abundances are high (Powell, 2003; Regier et al., 2015). Most adult moths within the Heliozelidae possess fundamentally dark wing colouration with iridescent scaling (Scoble, 1992; Powell, 2003).

Larval instars are obligate leaf miners, with the exception of the final instar (Stehr, 1992; Regier et al., 2015). A flat, lenticular case is constructed by the penultimate instar from the epidermal layers of a mined leaf, lined and bound with silk to form a firm, cocoon-type covering (Holloway et al., 1987; Stehr, 1992; Regier et al., 2015). The vernacular name, "shield bearers", refers specifically to the oval, lenticular shape of the crafted casing (Scoble, 1992; Davis, 1998). The casing is either suspended by means of a silken thread,

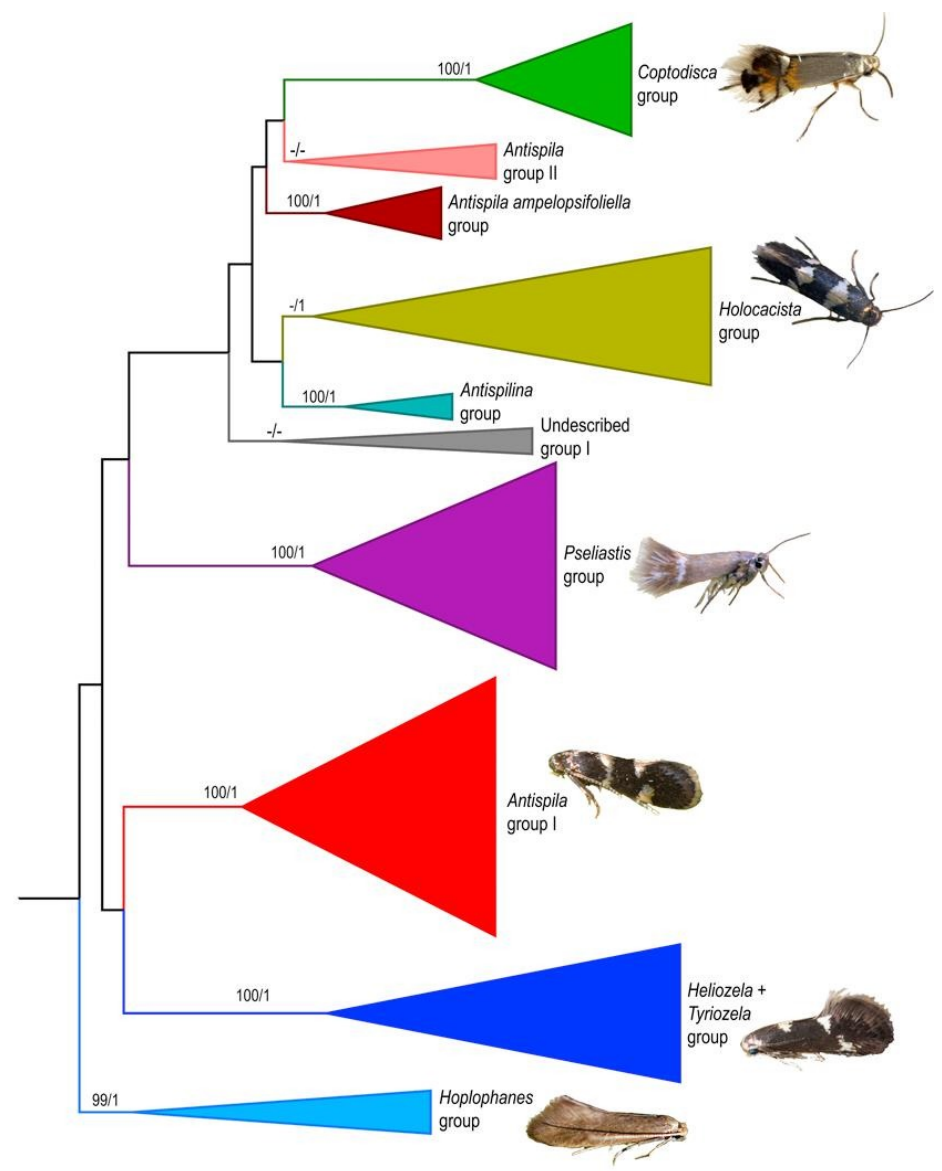

FIGURE 1

The maximum likelihood tree compiled by Milla et al. (2018) that represents the major genera within the Heliozelidae. 
or carried or dragged from the infested leaf by the encased larvae (Scoble, 1992; Regier et al., 2015). The larvae anchor themselves by weaving a silken mat onto objects with which they come into contact.

Detailed accounts of the morphology of all the life stages of the Heliozelidae have been documented by Bourgogne (1951), Hering (1951), Holloway et al. (1987), Scoble (1992), Davis (1998), Powell (2003) and Patočka and Turčáni (2005). Keys in Mey (2011) and Patočka and Turčáni (2005) enable the identification of some genera and species within the Heliozelidae.

Almost all individual heliozelid species are hostplantspecific, confined to genus level or, at least, the plant family level (Regier et al., 2015), which may lead to gregarious behaviour, depending on local plant assemblages. Within the agricultural context, a number of heliozelids are considered to be of economic importance (Table 1). Over the last three decades, four heliozelid species have unexpectedly been encountered on commercial grapevines. These are Antispila oinophylla Van Nieukerken \& Wagner (reported in Northern Italy in 2007, one of the two species of North American origin), Antispila uenoi Kuroko (a pest native to Japan, reported on commercial vineyards (Kuroko, 1987; Ueno et al., 1987) and $H$. capensis (a pest thought to be a native species, presently reported on commercial vineyards in South Africa) (Van Nieukerken \& Geertsema, 2015).

\section{HOLOCACISTA CAPENSIS}

Holocacista capensis is a multivoltine (having several generations per year) pest present throughout a grapevine growing season (Van Nieukerken \& Geertsema, 2015; Torrance, 2016).

\section{Morphology and known biology}

The adults are small, diurnal moths with a wingspan of ca. $3.9 \mathrm{~mm}$ to $4.9 \mathrm{~mm}$ (Van Nieukerken \& Geertsema, 2015). The black ground colour of the wings is ornamented by silvery-white spots or fascia. The head and face are covered by silvery-white metallic, appressed scales. Male and female moths can be differentiated based on the colour of the posterior abdominal segments (lead-coloured in males, jet black in females) and the markings on their forewings (in females the first costal and dorsal spots are joined to form a contiguous band) (Fig. 2). The adults of $H$. capensis closely resemble Holocacista salutans (Meyrick) and Holocacista varii (Meyrick). Eggs are laid singly in leaves by females after mating (Van Nieukerken \& Geertsema, 2015).

The larvae develop through four feeding instars (Van Nieukerken \& Geertsema, 2015). These larvae are unable to move to other leaves upon damage to the natal leaf or mine (Torrance, 2016). The heads of feeding larvae are usually characterised by dark, prognathous head capsules. Their bodies are yellow or whitish (Van Nieukerken \& Geertsema, 2015). The larvae feed on leaf tissue only (Torrance, 2016) and completed mines reach $12 \mathrm{~mm}$ to $15 \mathrm{~mm}$ in length (Van Nieukerken \& Geertsema, 2015). The fifth, final instar is non-feeding and constructs the cocoon casing in which it will pupate.

\section{Symptoms of damage}

The mining activities of larvae cause physical damage to the infested grapevine leaves. The effect of the mines on the photosynthetic ability of a grapevine is not yet known, although it appears to be limited (Van Nieukerken \& Geertsema, 2015). The mines are predominantly present along the leaf margin. When high infestations are reported, it is usually later in a growing season, usually after harvest, or when leaf miner populations were left unmanaged.

The final instar larva in its cocoon casing descends from the leaf by means of a silken thread (similar to most other leaf-mining heliozelids) (Torrance, 2016). Upon landing on an object in its immediate surroundings (e.g. leaf, trellis post or grape bunch), the larva will move to an appropriate location and firmly attach itself to the object (Van Nieukerken \& Geertsema, 2015; Torrance, 2016). It therefore is undesirable if the cocoon casings are present on fruit intended for consumption.

\section{Bio-ecology}

Larval and adult abundance tends to increase throughout a season, coupled with a rise in the prevailing temperatures (Torrance, 2016). February and March mark the peak in adult

\begin{tabular}{c|c|c}
\hline WING PATTERN & ABDOMEN \\
\hline FALE & MALE \\
\hline & FEMALE
\end{tabular}

FIGURE 2

Different wing (indicated by red arrows) and abdominal patterns of male and female Holocacista capensis adults. Adapted from Torrance (2016). 
and larval abundance (Van Nieukerken \& Geertsema, 2015; Torrance, 2016). According to Torrance (2016), temperature plays a vital role in leaf miner population abundance. Other variables (including trellis angle and block aspect) affecting leaf miner infestation were also investigated, but definite conclusions regarding their specific effect on population numbers could not be drawn (Torrance, 2016).

It is estimated that the life cycle of the moth takes at least seven weeks to complete, and a minimum of four generations can be present within a growing season (Torrance, 2016). The leaf miner overwinters in the larval or pupal life stage within the cocoon casing that is sheltered from the elements (e.g. under the bark of a grapevine stem, in leaf litter or in the crevices of trellising posts) (Torrance, 2016). These individuals will eclose in the ensuing growing season and will produce the first generation in the new season (Van Nieukerken \& Geertsema, 2015; Torrance, 2016).

Holocacista capensis is widely distributed throughout the Western Cape, South Africa and has established itself in relatively high abundances in some of the major table grapeproducing regions in southern Africa (Fig. 3) (Torrance, 2016). Synonymy amongst populations (molecular identifications) has not yet been confirmed.

\section{VARIABLES AFFECTING LEAF MINER INFESTATION}

Auerbach et al. (1995) state that the dominant cause of mortality or absence of leaf miner populations in suitable habitats can be attributed to vertical (interactions between miners, host plants and natural enemies) and horizontal interactions (including inter- and intraspecific interactions between miners and herbivores). This does not, however, account for environmental and abiotic factors affecting leaf miner infestation.

Little is known of the direct effects of abiotic factors or variables on leaf miner abundance and survival (Auerbach et al., 1995). Pereira et al. (2007) identified rainfall as an important factor affecting mortality of Leucoptera coffeella (Guérin-Méneville \& Perrottet) (Lepidoptera: Lyonetiidae), and also considered that weather conditions could affect egg mortality. However, their study concentrated on the environmental factors operative between the two seasons (rainy vs. dry) and not necessarily on the factors influencing population abundances within a particular season. Potter (1992) excluded shade as an important factor affecting the abundance of Phytomyza ilicicola Loew (Diptera: Agromyzidae). A study by Johns and Hughes (2002) indicated a negative association between emergence success and adult weight of Dialectica scalariella Zeller (Lepidoptera: Gracillariidae) in Paterson's curse, Echium plantagineum (Boraginaceae), and elevated $\mathrm{CO}_{2}$ as a result of reduced foliar quality of $E$. plantagineum. The invasion ecology of the horse chestnut leaf miner, Cameraria ohridella Deschka \& Dimić (Lepidoptera, Gracillariidae), on the other hand, has been found to be affected by long-distance dispersal and increased human population densities (increasing the probability of accidental transport of leaf miners as a result) (Gilbert et al., 2004).

In the case of $H$. capensis, the average adult male abundance has been strongly correlated with the average minimum humidity (and thus also the average maximum temperature) (Torrance, 2016). Edge effects, the difference between externally located plots and internally located plots, did not affect leaf miner abundance. Spatial distribution and abundance in grapevine blocks have not been assessed,

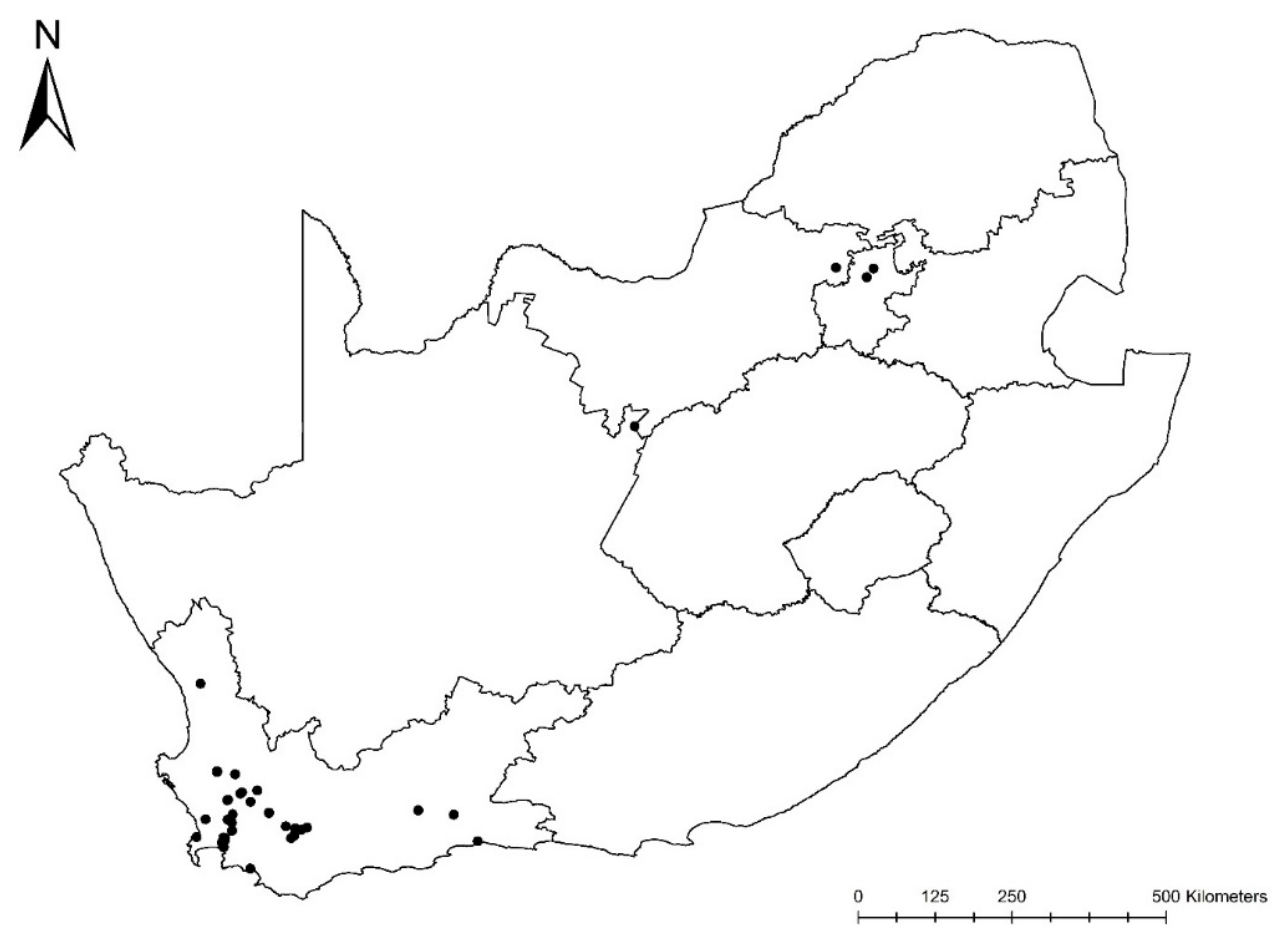

FIGURE 3

Recorded distribution of Holocacista capensis (Van Nieukerken \& Geertsema, 2015; Torrance, 2016). 
however, and require further investigation. Human-mediated means of dispersal have also been speculated (Torrance, 2016).

\section{PEST MANAGEMENT}

On a global scale, most commercial vineyards are protected against leaf-mining pests (as with a number of other pests) by the use of insecticides (Maier, 2001). However, various other control strategies have also been used to control pest populations. A summary of these strategies and their respective leaf-mining insect targets is given in Tables 2 to 4 .

\section{Chemical control}

Chemical control can be achieved through the use of synthetic chemical insecticides or botanical insecticides (Isman, 2006) (Table 2). In terms of environment-friendly pest management, botanical insecticides pose an attractive alternative to the use of synthetic insecticides, being less of a threat to human health or to the environment. Generally speaking, synthetic pesticides exhibit some adverse effects, such as their toxicity for non-target organisms, contamination of groundwater and the development of pesticide resistance in pest populations (Isman, 2006).

Short-term (seasonal) control of H. capensis has been achieved in vineyards where dichlorvos and spinosad were applied (Torrance, 2016). Extensive research has been conducted on insecticide use and the corresponding insecticide resistance of Tuta absoluta (Meyrick) (Lepidoptera: Gelechiidae) (Biondi et al., 2018), raising concern about long-term control strategies for other leafmining pests with similar generation times, including H. capensis.

\section{Entomopathogenic nematodes}

Of the various beneficial, parasitic groups within the nematode complex, entomopathogenic nematodes (EPNs) are used to control insect pests (Stock \& Hunt, 2005; Stock, 2015). The genera within this group include members of the genera Steinernema Travassos (Steinernematidae: Rhabditida) and Heterorhabditis Poinar (Heterorhabditidae: Rhabditida) (Kaya et al., 1993). Together with their associated pathogenic bacteria (from the genus Xenorhabdus and Photorhabdus for steinernematids and heterorhabditids respectively), EPNs kill their hosts within a few days (Dillman et al., 2012, Lewis et al., 2015).

For all EPNs there is a free-living, non-feeding stage known as the infective juvenile (IJ) or dauer (Griffin et al., 2005). When an appropriate host is located, an IJ will enter through any natural opening (e.g., mouth or anus), the cuticle or spiracles in search of the nutrient-rich haemolymph. Here, the IJs will release their symbiotic bacteria from their intestines; these reproduce and release toxins. The infected insect usually succumbs within $48 \mathrm{~h}$. Within the cadaver, the IJs feed on the bioconverted host tissues (and bacteria), grow and develop into adults. As the food source becomes scant within the cadaver, the nematodes develop in crowded conditions and become arrested as IJs. The new IJs, with their specific symbiotic bacteria, will emerge from the cadaver in search of a new host (Griffin et al., 2005).

In a study by Steyn et al. (2019), high mortality of 


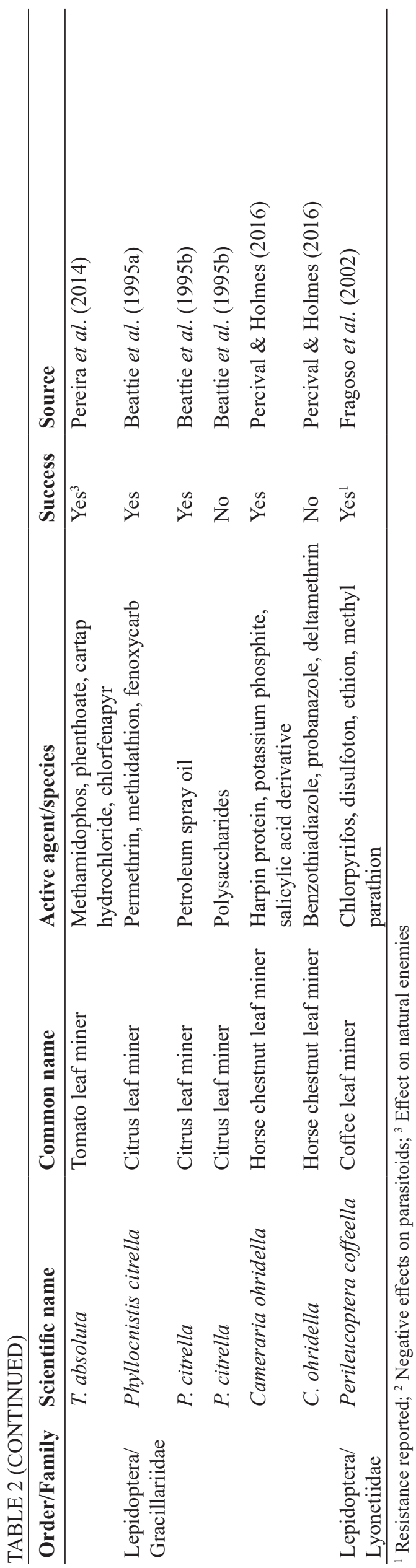

H. capensis larvae was obtained for Heterorhabditis baujardi Phan, Subbotin, Nguyen \& Moens (92\%), Heterorhabditis noenieputensis Malan, Knoetze \& Tiedt (85\%) and Heterorhabditis indica Poinar, Karunakar \& David (83\%). Almost double the number of $H$. noenieputensis (34 nematodes/insect) penetrated the insect larvae in comparison with the other two EPNs. However, the relative potency of $H$. baujardi was 3.56 times higher than it was for $H$. indica, whilst that of $H$. indica was 2.57 times higher than it was for H. noenieputensis. These authors concluded that the results obtained in the laboratory were encouraging, especially with regard to the nematodes' ability to penetrate the leaf-mining galleries and to infect the larvae successfully.

A variety of EPNs have successfully controlled certain leaf-mining pest populations (Table 3). In the case of T. absoluta, leaf bioassays conducted on leaves infested with larvae, using concentrations of $1000 \mathrm{IJs} / \mathrm{ml}$ (equivalent to a $60 \mathrm{IJ} / \mathrm{cm}^{2}$ dose) of Steinernema carpocapsae (Weiser, 1955) Wouts, Mráček, Gerdin \& Bedding, Steinernema feltiae (Filipjev, 1934) Wouts, Mráček, Gerdin \& Bedding and Heterorhabditis bacteriophora Poinar caused high levels of mortality $(88.6 \%, 92 \%$ and $76.3 \%$, respectively) after $72 \mathrm{~h}$ of exposure to the respective EPNs (Batalla-Carrera et al., 2010). These results revealed that the EPNs were able to find and kill larvae, despite their relative position on or within a leaf (i.e. outside of or within leaf galleries). Field trials conducted by Gözel and Kasap (2015) with the same EPNs on netted plants, using a conventional airblast-sprayer at an application rate of $50 \mathrm{IJs} / \mathrm{cm}^{2}$, confirmed these results (ca. $46 \%, 92 \%$ and $82 \%$ total mortality, respectively). Similar results were obtained by Van Damme et al. (2015), who applied a concentration of $27.3 \mathrm{IJs} / \mathrm{cm}^{2}$ of each of the three EPN species to infested leaves by means of an automated spray boom. Beattie et al. (1995b) tested S. carpocapsae against the larvae of Phyllocnists citrella Stainton (Lepidoptera: Gracillariidae) at concentrations of $5 \times 10^{6}$, $10 \times 10^{6}$ and $30 \times 10^{6} \mathrm{IJs} / 1$ water. A significant increase in mortality was only obtained at the highest dose, resulting in $35 \%$ mortality.

\section{Parasitoids}

In contradiction to the inferences made by Ayabe and Hijii (2016) regarding the study by Connor and Taverner (1997), the leaf-mining habit does not allow leaf miners to escape predation. According to Connor and Taverner (1997), the loss of mobility, and thus escape strategies, in leaf-mining insects has led to higher mortality rates associated with hymenopteran parasitoids than in exophagous insects. This has led to the evolution of more species of associated parasitoids than in any other insect-feeding guild. In the case of $H$. capensis, several parasitoids have been found to attack the larval and pupal life stages, although these parasitoids have not yet been identified. The use of parasitoids against leaf-mining insects is a popular alternative to the use of insecticides.

A few case studies with promising results are listed in Table 4. Trichogrammatidae, Encyrtidae and Eulophidae (all of which belong to the superfamily Chalcidoidea) have been found to parasitize lepidopteran leaf-mining pests (Table 4). The species within the Chalcidoidea are generally less than 


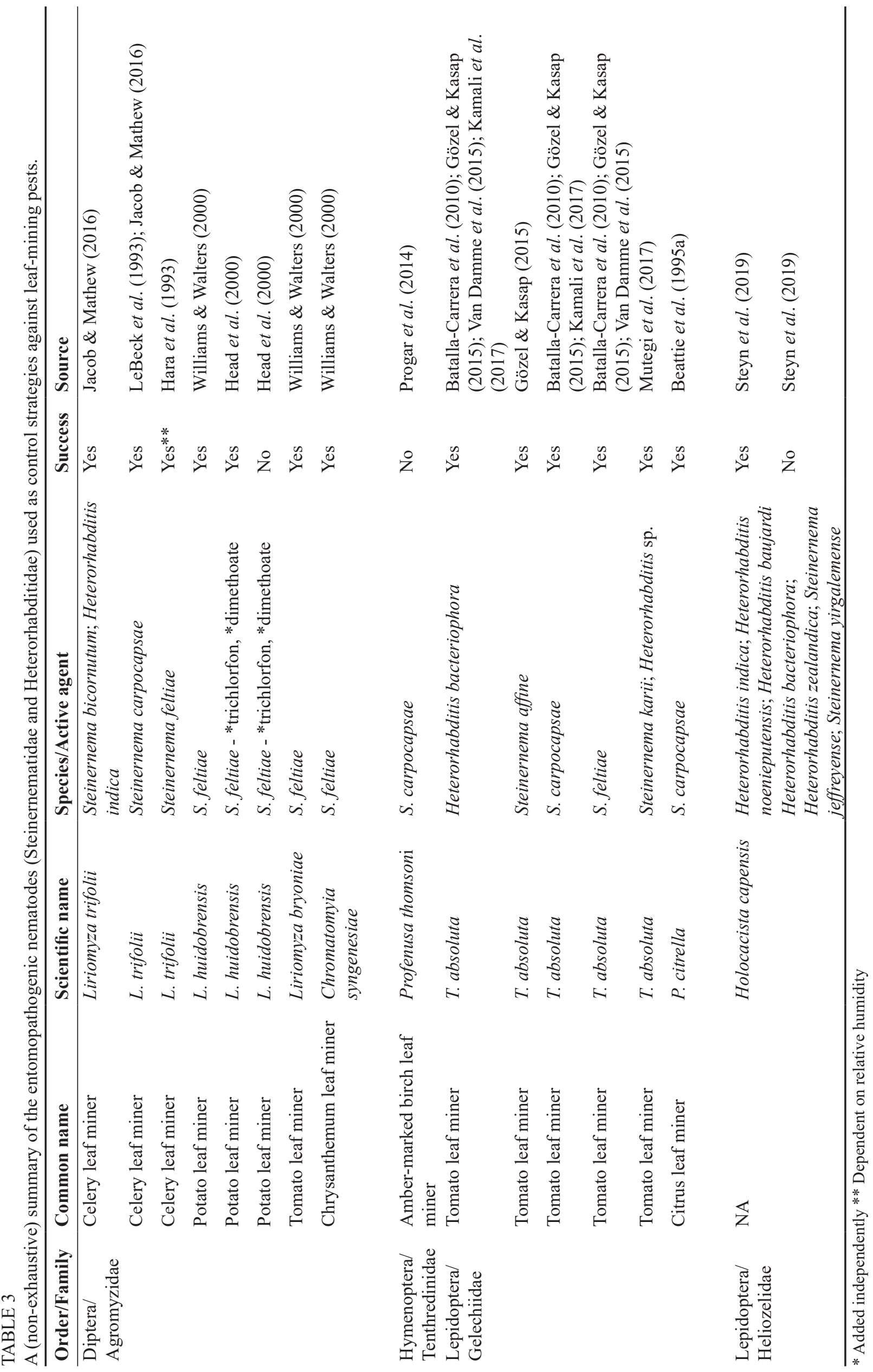


TABLE 4

A (non-exhaustive) summary of parasitoids used as control strategies against leaf-mining pests.

\begin{tabular}{|c|c|c|c|c|c|}
\hline Order/family & Common name & Scientific name & Species/Family & Success & Source \\
\hline \multirow[t]{9}{*}{$\begin{array}{l}\text { Diptera/ } \\
\text { Agromyzidae }\end{array}$} & Celery leaf miner & Liriomyza trifolii & $\begin{array}{l}\text { Chrysocharis flacilla } \\
\text { (Eulophidae) }\end{array}$ & Yes & $\begin{array}{l}\text { Muchemi et al. } \\
\text { (2018) }\end{array}$ \\
\hline & Celery leaf miner & L. trifolii & Diglyphus isaea (Eulophidae) & Yes & $\begin{array}{l}\text { Minkenberg \& Van } \\
\text { Lenteren (1986) }\end{array}$ \\
\hline & Potato leaf miner & L. huidobrensis & C. flacilla & Yes & $\begin{array}{l}\text { Muchemi et al. } \\
\text { (2018) }\end{array}$ \\
\hline & Potato leaf miner & L. huidobrensis & D. isaea & Yes & $\begin{array}{l}\text { Maharjan et al. } \\
(2017)\end{array}$ \\
\hline & Potato leaf miner & L. huidobrensis & Opius dissitus (Braconidae) & Yes & Wei \& Kang (2006) \\
\hline & Vegetable leaf miner & Liriomyza sativae & O. dissitus & Yes & Wei \& Kang (2006) \\
\hline & Vegetable leaf miner & L. sativae & C. flacilla & Yes & $\begin{array}{l}\text { Muchemi et al. } \\
\text { (2018) }\end{array}$ \\
\hline & Holly leaf miner & Phytomyza ilicis & $\begin{array}{l}\text { Chrysocharis gemma } \\
\text { (Eulophidae) }\end{array}$ & Yes & $\begin{array}{l}\text { Heads \& Lawton } \\
\text { (1983) }\end{array}$ \\
\hline & Holly leaf miner & P. ilicis & Opius ilicis (Braconidae) & Yes & $\begin{array}{l}\text { Kirichenko et al. } \\
\text { (2018) }\end{array}$ \\
\hline \multirow[t]{2}{*}{$\begin{array}{l}\text { Hymenoptera/ } \\
\text { Tenthredinidae }\end{array}$} & $\begin{array}{l}\text { Amber-marked birch } \\
\text { leaf miner }\end{array}$ & $\begin{array}{l}\text { Profenusa } \\
\text { thomsoni }\end{array}$ & $\begin{array}{l}\text { Lathrolestes thomsoni } \\
\text { (Ichneumonidae) }\end{array}$ & Yes & Soper et al. (2015) \\
\hline & Birch leaf miner & Fenusa pumila & $\begin{array}{l}\text { Lathrolestes nigricollis } \\
\text { (Ichneumonidae), } \\
\text { Grypocentrus albipes } \\
\text { (Ichneumonidae) }\end{array}$ & Yes & Langor et al. (2000) \\
\hline \multirow[t]{2}{*}{$\begin{array}{l}\text { Lepidoptera/ } \\
\text { Gelechiidae }\end{array}$} & Tomato leaf miner & T. absoluta & $\begin{array}{l}\text { Trichogramma euproctidis, } \\
\text { Trichogramma achaeae } \\
\text { (Trichogrammatidae) }\end{array}$ & Yes & $\begin{array}{l}\text { El-Arnaouty et al. } \\
\text { (2014) }\end{array}$ \\
\hline & Tomato leaf miner & T. absoluta & $\begin{array}{l}\text { Trichogramma pretiosum } \\
\text { (Trichogrammatidae) }\end{array}$ & Yes & $\begin{array}{l}\text { Parra \& Zucchi } \\
(2004)\end{array}$ \\
\hline \multirow[t]{2}{*}{$\begin{array}{l}\text { Lepidoptera/ } \\
\text { Gracillariidae }\end{array}$} & Citrus leaf miner & P. citrella & $\begin{array}{l}\text { Ageniaspis citricola } \\
\text { (Encyrtidae) }\end{array}$ & Yes & Hoy et al. (2007) \\
\hline & Citrus leaf miner & P. citrella & $\begin{array}{l}\text { Citrostichus phyllocnistoides } \\
\text { (Eulophidae) }\end{array}$ & Yes & $\begin{array}{l}\text { Garcia-Marí et al. } \\
\text { (2004) }\end{array}$ \\
\hline
\end{tabular}

$3 \mathrm{~mm}$ in length, making it rather difficult to collect and study individuals (Noyes, 2003).

\section{Cover cropping}

Ingels and Klonsky (1998) describe a cover crop as a crop (or secondary plants) of little to no economic significance that is grown in intra- and inter-rows of vineyards, the presence of which, however, provides numerous other potential benefits. Parolin et al. (2012) provide an extended definition of barrier plants, as "... a plant which is used within or bordering a primary crop for the purpose of disease suppression and/ or interception of pests and/or pathogens". In terms of their potential to harbour pests and pathogens, the effect of barrier plants or cover crops on population numbers of most leafmining pests is not known and should be investigated, as the use of different cover crops to reduce pests in vineyards is regarded as an option in the future.

\section{OTHER PEST MANAGEMENT METHODS}

Entomopathogenic fungi (EPF) have been used successfully in a variety of integrated pest management (IPM) strategies against many leaf-mining pests of economic importance (Shah \& Pell, 2003). Various strains of Metarhizium anisopliae (Metschnikoff) (Sorokin) (Hypocreales: Clavicipitaceae) and Beauveria bassiana (Balsamo) (Vuillemin) (Hypocreales: Cordycipitaceae) have been used to control the pea leaf miner, Liriomyza huidobrensis (Blanchard) (Diptera: Agromyzidae) (Migiro et al., 2010; 2011); and the tomato leaf miner, T. absoluta (Rodríguez et al., 2006; Allegrucci et al., 2017).

Mating disruption implies the use of a formulated female pheromone to disrupt or regulate the mating habits of a target pest species (Cardé \& Minks, 1995). Amongst the leaf-mining Lepidoptera, mating disruption has only been explored and successfully achieved against $P$. citrella (Stelinski et al., 2008; Stelinski et al., 2010; Willett et al., 2015). Mating disruption studies on T. absoluta have only proved successful under greenhouse conditions (Vacas et al., 2011; Cocco et al., 2013).

The practice of bagging grapes (as a physical measure of control) using a bunch cover/bag dates back to 1919 (Signes et al., 2007). After ripening, bunches are typically 
covered with a cover/bag which is only removed during harvest. Bagging has been used to promote uniform colour development within a bunch, reduce the incidence of blemished fruit, reduce the incidence of disease, delay the ripening process (ideally when harvest needs to be delayed for increased market access), increase hygiene (reduced contact with pesticides sprays and other contaminants), protect grape bunches against adverse environmental variables (e.g. moisture, hail, sunburn and cracking/bursting of fruit), and to provide protection against attack by birds and insects (Signes et al., 2007; Sharma et al., 2014). Pre-harvest fruit bagging has been used to avoid insect infestation in a variety of crops (Sharma et al., 2014).

The use of netting (overhead netting, vineyard layover netting and zone netting) in vineyards has become widespread in recent years (Suvočarev et al., 2013). Netting is used to reduce the number of pests (reduced immigrant invasion from surrounds), leading to a reduction in the number of pesticide applications; reduce radiation exposure of plants during hot summer months; and minimise hail and bird damage (Suvočarev et al., 2013). Neither bagging of grapes nor netting, however, has been tested to exclude leafmining pests.

\section{RECOMMENDATIONS}

The discovery of a newly recognised pest in an industry that contributes to a country's economy requires novel and baseline studies to understand the pest's ecology and distribution so that pest populations can be controlled adequately. The use of dichlorvos and spinetoram has been used to reduce the density of $H$. capensis populations in infested vineyards. When studying and considering the various control options, however, it is important to consider the restrictions imposed on growers regarding the use of harmful chemical insecticides and the effect of insecticides on the evolution of insecticide resistance. The investigation of alternative control strategies therefore is pertinent in enhancing IPM strategies. It is clear that there is potential for the use of parasitoid wasps and EPNs to control H. capensis. The review highlights the need to commercialise smaller, native EPN species and to test a variety of parasitoids (especially the trichogrammatids, encyrtid and eulophid species identified in this review) against $H$. capensis in the laboratory and field environments. Furthermore, continued research will increase the current knowledge of $H$. capensis and the use of chemical and biological control options that potentially could be used as a reference for studies focused on other emerging leaf-mining pests, such as T. absoluta, in South Africa.

\section{LITERATURE CITED}

Allegrucci, N., Velazquez, M.S., Russo, M.L., Perez, E. \& Scorsetti, A.C., 2017. Endophytic colonisation of tomato by the entomopathogenic fungus Beauveria bassiana: The use of different inoculation techniques and their effects on the tomato leafminer Tuta absoluta (Lepidoptera: Gelechiidae). J. Plant Protect. Res. 57, 205-211. doi:10.1515/jppr-2017-0045

Allsopp, E., Barnes, B.N., Blomefield, T.L. \& Pringle, K.L., 2015 Grapevine. In: Prinsloo, G.L. \& Uys, V.M. (eds). Insects of cultivated plants and natural pastures in southern Africa. Entomological Society of Southern Africa, Cape Town, South Africa. pp. 420 - 437.
Auerbach, M.J., Connor, E.F. \& Mopper, S., 1995. Minor miners and major miners: Population dynamics of leaf-mining insects. In: Cappuccinco, N. \& Price, P.W. (eds). Population dynamics: New approaches and synthesis. Academic Press, San Diego, United States. pp. 83 - 110.

Ayabe, Y. \& Hijii, N., 2016. Avoidance of parasitoid attack is associated with the spatial use within a leaf by a lepidopteran leafminer. Entomol. Exp. Appl. 161, 39-49. doi:10.1111/eea.12492

Batalla-Carrera, L., Morton, A. \& García-del-Pino, F., 2010. Efficacy of entomopathogenic nematodes against the tomato leafminer Tuta absoluta in laboratory and greenhouse conditions. BioControl 55, 523-530. doi:10.1007/ s10526-010-9284-z

Beattie, G.A.C., Liu, Z.M., Watson, D.M., Clift, A.D. \& Jiang, L., 1995a. Evaluation of petroleum spray oils and polysaccharides for control of Phyllocnistis citrella Stainton (Lepidoptera: Gracillariidae). Aust. J. Entomol. 34, 349-353. doi:10.1111/j.1440-6055.1995.tb01353.x

Beattie, G.A.C., Somsook, V., Watson, D.M., Clift, A.D. \& Jiang, L., 1995b. Field evaluation of Steinernema carpocapsae (Weiser) (Rhabditida: Steinernematidae) and selected pesticides and enhancers for control of Phyllocnistis citrella Stainton (Lepidoptera: Gracillariidae). Aust. J. Entomol. 34, 335-342. doi:10.1111/j.1440-6055.1995.tb01351.x

Bennett, A., 2015. Cotton. In: Prinsloo, G.L. \& Uys, V.M. (eds). Insects of cultivated plants and natural pastures in southern Africa. Entomological Society of Southern Africa, Cape Town, South Africa. pp. 274 - 293.

Bernardo, U., Van Nieukerken, E.J., Sasso, R., Gebiola, M., Gualtieri L. \& Viggiani, G., 2015. Characterization, distribution, biology and impact on Italian walnut orchards of the invasive North-American leafminer Coptodisca lucifluella (Lepidoptera: Heliozelidae). Bull. Entomol. Res. 105, 210-224. doi:10.1017/S0007485314000947

Biondi, A., Guedes, R.N.C., Wan, F.-H. \& Desneux, N., 2018. Ecology, worldwide spread, and management of the invasive South American tomato pinworm, Tuta absoluta: Past, present and future. Annu. Rev. Entomol. 63, 239-258. doi:10.1146/annurev-ento-031616-034933

Bourgogne, J., 1951. Ordre des Lepidopteres. In: Traité de Zoologie. Masson Et Cie Éditeurs, Paris, France. pp. 300 - 448.

Boush, G.M. \& Anderson, R.J., 1967. Coptodisca sp. (Lepidoptera: Heliozelidae) attacking cranberries in Wisconsin. J. Econ. Entomol. 60, 1472. doi:10.1093/jee/60.5.1472

Buthelezi, N.M., Conlong, D.E. \& Zharare, G.E., 2012. The groundnut leaf miner collected from South Africa is identified by mtDNA CO1 gene analysis as the Australian soybean moth (Aproaerema simplixella) (Walker) (Lepidoptera: Gelechiidae). Afr. J. Agric. Res. 7, 5285-5292. doi:10.5897/ AJAR12.986

Cardé, R.T. \& Minks, A.K., 1995. Control of moth pests by mating disruption: Successes and constraints. Annu. Rev. Entomol. 40, 559-585. doi:10.1146/annurev.en.40.010195.003015

Cocco, A., Deliperi, S. \& Delrio, G., 2013. Control of Tuta absoluta (Meyrick) (Lepidoptera: Gelechiidae) in greenhouse tomato crops using the mating disruption technique. J. Appl. Entomol. 137, 16-28. doi:10.1111/ j.1439-0418.2012.01735.x

Connor, E.F. \& Taverner, M.P., 1997. The evolution and adaptive significance of the leaf-mining habit. Oikos 79, 6-25. doi:10.2307/3546085

Cornell, H.V., 1989. Endophage-ectophage ratios and plant defence. Evol. Ecol. 3, 64-76. doi:10.1007/BF02147932

Davis, D.R., 1998. The Monotrysian Heteroneura. In: Kristensen, N.P. (ed). Lepidoptera, moths and butterflies. 1, Evolution, systematics, and biogeography. Handbook of Zoology Vol 4, Part 35. Walter de Gruyter, Berlin, Germany. pp. $65-90$. 
Digweed, S.C., Macquarrie, C.J.K., Langor, D.W., Williams, D.J.M., Spence, J.R., Nystrom, K.L. \& Morneau, L., 2009. Current status of invasive alien birch-leafmining sawflies (Hymenoptera: Tenthredinidae) in Canada, with keys to species. Can. Entomol. 141, 201-235. doi:10.4039/n09-003

Dillman, A.R., Chaston, J.M., Adams, B.J., Ciche, T.A., Goodrich-Blair, H., Stock, S.P. \& Sternberg, P.W., 2012. An entomopathogenic nematode by any other name. PLOS Pathog. 8, 1-4. doi:10.1371/journal.ppat.1002527

Dos Santos, M.M., Soares, M.A., Silva, I.M., Fontes, P.C.R. \& Zanuncio, J.C., 2018. First record of the sweet potato pest Bedellia somnulentella (Lepidoptera: Bedelliidae) in Brazil. Fla. Entomol. 101, 315-316. doi:10.1653/024.101.0224

Du Plessis, H., 2015. Groundnut. In: Prinsloo, G.L. \& Uys, V.M. (eds). Insects of cultivated plants and natural pastures in southern Africa. Entomological Society of Southern Africa, Cape Town, South Africa. pp. $186-197$.

El-Arnaouty, S.A., Pizzol, J., Galal, H.H., Kortam, M.N., Afifi, A.I., Beyssat, V., Desneux, N., Biondi, A. \& Heikal, I.H., 2014. Assessment of two Trichogramma species for the control of Tuta absoluta in North African tomato greenhouses. Afr. Entomol. 22, 801-809. doi:10.4001/003.022.0410

Feeny, P., 1970. Seasonal changes in oak leaf tannin and nutrients as a cause of spring feeding by winter moth caterpillars. Ecology 51, 565-581. doi: $10.2307 / 1934037$

Ferguson, J.S., 2004. Development and stability of insecticide resistance in the leafminer Liriomyza trifolii (Diptera: Agromyzidae) to cyromazine, abamectin, and spinosad. J. Econ. Entomol. 97, 112-119. doi:10.1093/ jee/97.1.112

Fragoso, D.B., Guedes, R.N.C., Picanço, M.C. \& Zambolim, L., 2002. Insecticide use and organophosphate resistance in the coffee leaf miner Leucoptera coffeella (Lepidoptera: Lyonetiidae). Bull. Entomol. Res. 92, 203-212. doi:10.1079/BER2002156

Garcia-Marí, F., Vercher, R., Costa-Comelles, J., Marzal, C. \& Villalba, M., 2004. Establishment of Citrostichus phyllocnistoides (Hymenoptera: Eulophidae) as a biological control agent for the citrus leafminer Phyllocnistis citrella (Lepidoptera: Gracillariidae) in Spain. Biol. Control 29, 215-226. doi:10.1016/S1049-9644(03)00155-5

Gilbert, M., Grégoire, J.C., Freise, J.F. \& Heitland, W., 2004. Long-distance dispersal and human population density allow the prediction of invasive patterns in the horse chestnut leafminer Cameraria ohridella. J. Anim. Ecol. 73, 459-468. doi:10.1111/j.0021-8790.2004.00820.x

Gözel, Ç.\& Kasap, İ., 2015. Efficacy of entomopathogenic nematodes against the tomato leafminer, Tuta absoluta (Meyrick) (Lepidoptera: Gelechiidae) in tomato field. Turk. Entomol. Derg. 39, 229-237. doi:10.16970/ted.84972

Griffin, C.T., Boemare, N.E. \& Lewis, E.E., 2005. Biology and behaviour. In: Grewal, P.S., Ehlers, R.-U. \& Shapiro-Ilan, D.I. (eds). Nematodes as biocontrol agents. CABI Publishing, Wallingford, Oxfordshire. pp. $47-64$.

Grové, T., De Villiers, E.A. \& Daneel, M.S., 2015. Mango. In: Prinsloo, G.L. \& Uys, V.M. (eds). Insects of cultivated plants and natural pastures in southern Africa. Entomological Society of Southern Africa, Cape Town, South Africa. pp. $574-588$.

Haddi, K., Berger, M., Bielza, P., Rapisarda, C., Williamson, M.S. \& Bass, C., 2017. Mutation in the ace-1 gene of the tomato leaf miner (Tuta absoluta) associated with organophosphates resistance. J. Appl. Entomol. 141, 612-619. doi:10.1111/jen.12386

Hara, A.H., Kaya, H.K., Gaugler, R., LeBeck, L.M. \& Mello, C.L., 1993. Entomopathogenic nematodes for biological control of the leafminer, Liriomyza trifolii (Dipt.: Agromyzidae). Entomophaga 38, 359-369. doi:10.1007/BF02374454
Head, J., Walters, K.F.A. \& Langton, S., 2000. The compatibility of the entomopathogenic nematode, Steinernema feltiae, and chemical insecticides for the control of the South American leafminer, Liriomyza huidobrensis. BioControl 45, 345-353. doi:10.1023/A:1009986217310

Heads, P.A. \& Lawton, J.H., 1983. Studies on the natural enemy complex of the holly leaf-miner: The effects of scale on the detection of aggregative responses and the implications for biological control. Oikos 40, 267-276. doi: $10.2307 / 3544591$

Hering, E.M., 1951. Biology of the leaf miners. W. Junk, Gravenhages, The Netherlands.

Holloway, J.D., Bradley, J.D. \& Carter, D.J., 1987. CIE guides to insects of importance to man: 1. Lepidoptera. CAB International, Wallingford, Oxfordshire.

Hoy, M.A., Singh, R. \& Rogers, M.E., 2007. Citrus leafminer, Phyllocnistis citrella (Lepidoptera: Gracillariidae), and natural enemy dynamics in central Florida during 2005. Fla. Entomol. 90, 358-359. doi:10.1653/00154040(2007)90[358:CLPCLG]2.0.CO;2

Ingels, C.A. \& Klonsky, K.M., 1998. Historical and current uses. In: Ingels, C.A., Bugg, R.L., McGourty, G.T. \& Christensen, L.P. (eds). Cover cropping in vineyards: A grower's handbook. University of California Division of Agriculture and Natural Resources, Oakland, United States. pp. 3 - 7.

Isman, M.B., 2006. Botanical insecticides, deterrents, and repellents in modern agriculture and an increasingly regulated world. Annu. Rev. Entomol. 51, 45-66. doi:10.1146/annurev.ento.51.110104.151146

Jacob, J.S. \& Mathew, M.P., 2016. Laboratory evaluation of entomopathogenic nematodes against American serpentine leaf miner, Liriomyza trifolii (Burgess). J. Biopest. 9, 27-33.

Johns, C.V. \& Hughes, L., 2002. Interactive effects of elevated $\mathrm{CO}_{2}$ and temperature on the leaf-miner Dialectica scalariella Zeller (Lepidoptera: Gracillariidae) in Paterson's curse, Echium plantagineum (Boraginaceae). Glob. Chang. Biol. 8, 142-152. doi:10.1046/j.1365-2486.2002.00462.x

Kamali, S., Karimi, J. \& Koppenhöfer, A.M., 2017. New insight into the management of the tomato leaf miner, Tuta absoluta (Lepidoptera: Gelechiidae) with entomopathogenic nematodes. J. Econ. Entomol. 111, 112-119. doi:10.1093/jee/tox332

Kaya, H.K., Bedding, R.A. \& Akhurst, R.J., 1993. An overview of insectparasitic and entomopathogenic nematodes. In: Bedding, R., Akhurst, R. \& Kaya, H. (eds). Nematodes and the biological control of insect pests. CSIRO Publications, Melbourne, Australia. pp. $1-10$.

Khan, I.A., Hussain, S., Akbar, R., Saeed, M., Farid, A., Ali, I., Alam, M. \& Shah, B., 2015. Efficacy of bio- and synthetic pesticides against pea leaf miner, Phytomyza atricornis Goureau (Diptera: Agromyzidae), on pea in Peshawar. J. Entomol. Zool. Stud. 3, 368-370.

Kirichenko, N., Augustin, S. \& Kenis, M., 2018. Invasive leafminers on woody plants: A global review of pathways, impact, and management. J. Pest Sci. 92, 93-106. doi:10.1007/s10340-018-1009-6

Kroschel, J. \& Zegarra, O., 2013. Attract-and-kill as a new strategy for the management of the potato tuber moths Phthorimaea operculella (Zeller) and Symmetrischema tangolias (Gyen) in potato: Evaluation of its efficacy under potato field and storage conditions. Pest Manag. Sci. 69, 1205-1215. doi:10.1002/ps.3483

Kuroko, H., 1987. Three new species of the genus Antispila (Lepidoptera: Heliozelidae) from Japan. Tinea 12, 109-117.

Langor, D.W., Digweed, S.C., Williams, D.J.M., Spence, J.R. \& Saunders, C., 2000. Establishment and spread of two introduced parasitoids (Ichneumonidae) of the birch leafminer, Fenusa pusilla (Tenthredinidae). BioControl 45, 415-423. doi:10.1023/A:1026598305752 
LeBeck, L.M., Gaugler, R., Kaya, H.K., Hara, A.H. \& Johnson, M.W., 1993. Host stage suitability of the leafminer Liriomyza trifolii (Diptera: Agromyzidae) to the entomopathogenic nematode Steinernema carpocapsae (Rhabditida: Steinernematidae). J. Invertebr. Pathol. 62, 58-63. doi:10.1006/ jipa.1993.1074

Lee, S., Hodges, R.W. \& Brown, R.L., 2009. Checklist of Gelechiidae (Lepidoptera) in America north of Mexico. Zootaxa 2231, 1-39. doi:10.11646/zootaxa.2231.1.1

Lees, D.C., Kawahara, A.Y., Rougerie, R., Ohshima, I., Kawakita, A., Bouteleux, O., De Prins, J. \& Lopez-Vaamonde, C., 2014. DNA barcoding reveals a largely unknown fauna of Gracillariidae leaf-mining moths in the Neotropics. Mol. Ecol. Resour. 14, 286-296. doi:10.1111/1755-0998.12178

Lewis, E.E., Hazir, S., Hodson, A. \& Gulcu, B., 2015. Trophic relationships of entomopathogenic nematodes in agricultural habitats. In: CamposHerrera, R. (ed). Nematode pathogenesis of insects and other pests. Springer International Publishing, Cham, Switzerland. pp. 139 - 163.

Lomelí-Flores, J.R., Barrera, J.F. \& Bernal, J.S., 2010. Impacts of weather, shade cover and elevation on coffee leafminer Leucoptera coffeella (Lepidoptera: Lyonetiidae) population dynamics and natural enemies. Crop Prot. 29, 1039-1048. doi:10.1016/j.cropro.2010.03.007

Low, C., 2012. Variable risk and the evolution of the defence repertoire of the Tupelo leafminer. In: Pontarotti. P. (ed). Evolutionary biology: Mechanisms and trends. Springer, Berlin, Heidelberg, Germany. pp. 155 - 168.

Maharjan, R., Kwon, M., Kim. J. \& Jung, C., 2017. Mass production of Diglyphus isaea (Hymenoptera: Eulophidae), a biological control agent of a Korean population of potato leaf miner Liriomyza huidobrensis (Blanchard) (Diptera: Agromyzidae). Entomol. Res. 47, 94-100. doi:10.1111/17485967.12205

Maier, C.T., 2001. Exotic lepidopteran leafminers in North American apple orchards: Rise to prominence, management, and future threats. Biol. Invasions 3, 283-293. doi:10.1023/A:1015289928950

Mey, W., 2011. Basic pattern of Lepidoptera diversity in southwestern Africa. In: Hacker, H.H. (ed.). Esperiana: Buchreihe zur Entomologie. Memoir 6. Wissenschaftlicher Verlag Heinz Peks, Schwanfeld, Germany. pp. $1-316$.

Migiro, L.N., Maniania, N.K., Chabi-Olaye, A. \& Vandenberg, J., 2010. Pathogenicity of entomopathogenic fungi Metarhizium anisopliae and Beauveria bassiana (Hypocreales: Clavicipitaceae) isolates to the adult pea leafminer (Diptera: Agromyzidae) and prospects of an autoinoculation device for infection in the field. Environ. Entomol. 39, 468-475. doi:10.1603/ EN09359

Migiro, L.N., Maniania, N.K., Chabi-Olaye, A., Wanjoya, A. \& Vandenberg, J., 2011. Effect of infection by Metarhizium anisopliae (Hypocreales: Clavicipitaceae) on the feeding and oviposition of the pea leafminer Liriomyza huidobrensis (Diptera: Agromyzidae) on different host plants. Biol. Control 56, 179-183. doi:10.1016/j.biocontrol.2010.09.013

Milla, L., Van Nieukerken, E.J., Vijverberg, R., Doorenweerd, C., Wilcox, S.A., Halsey, M.A., Young, D.A., Jones, T.M. \& Kallies, A., 2018. A preliminary molecular phylogeny of shield-bearer moths (Lepidoptera: Adeloidea: Heliozelidae) highlights rich undescribed diversity. Mol. Phylogenetics Evol. 120, 129-143. doi:10.1016/j.ympev.2017.12.004

Minkenberg, O.P.J.M. \& Van Lenteren, J.C., 1986. The leafminers Liriomyza bryoniae and L. trifolii (Diptera: Agromyzidae), their parasites and host plants: A review. Agricultural University of Wageningen Papers No. 86(2).

Muchemi, S.K., Zebitz, C.P.W., Borgemeister, C., Akutse, K.S., Foba, C.N., Ekesi, S. \& Fiaboe, K.K.M., 2018. Interaction between Chrysocharis flacilla and Diglyphus isaea (Hymenoptera: Eulophidae), two parasitoids of Liriomyza leafminers. J. Econ. Entomol. 111, 556-563. doi:10.1093/jee/ toy007
Mutegi, D.M., Kilalo, D., Kimenju, J.W. \& Waturu, C., 2017. Pathogenicity of selected native entomopathogenic nematodes against tomato leaf miner (Tuta absoluta) in Kenya. World. J. Agric. Res. 5, 233-239. doi:10.12691/ wjar-5-4-5

Nielsen, E.S. \& Common, I.F.B., 1991 (2nd ed). Lepidoptera (moths and butterflies). In: The insects of Australia, Volume II. Melbourne University Press, Melbourne, Australia. pp. 817 - 915

Noyes, J.S., 2003. Universal Chalcidoidea Database: About Chalcidoids Natural History Museum [Online]. Retrieved 12 September, 2018, from: http://www.nhm.ac.uk/our-science/data/chalcidoids/introduction.html

Parolin, P., Bresch, C., Desneux, N., Brun, R., Bout, A., Boll, R. \& Poncet C., 2012. Secondary plants used in biological control: A review. Int. J. Pest Manag. 58, 91-100. doi:10.1080/09670874.2012.659229

Parra, J.R.P. \& Zucchi, R.A., 2004. Trichogramma in Brazil: Feasibility of use after twenty years of research. Neotrop. Entomol. 33, 271-81. doi:10.1590/S1519-566X2004000300001

Patočka, J. \& Turčáni, M., 2005. Lepidoptera pupae: Central European species. Apollo Books, Denmark.

Percival, G.C. \& Holmes, S.P., 2016. The influence of systematic inducing agents on horse chestnut leaf miner (Cameraria ohridella) severity in white flowering horse chestnut (Aesculus hoppicastanum L.). Urban For. Urban Green. 20,97-102. doi:10.1016/j.ufug.2016.08.009

Pereira, E.J.G., Picanço, M.C., Bacci, L., Crepso, A.L.B. \& Guedes, R.N.C. 2007. Seasonal mortality factors of the coffee leafminer, Leucoptera coffeella. Bull. Entomol. Res. 97, 421-432. doi:10.1017/S0007485307005202

Pereira, R.R., Picanço, M.C., Santana JR, P.A., Moreira, S.S., Guedes, R.N.C. \& Corrêa, A.S., 2014. Insecticide toxicity and walking response of three pirate bug predators of the tomato leaf miner Tuta absoluta. Agric. Forest Entomol. 16, 293-301. doi:10.1111/afe.12059

Potter, D.A., 1992. Abundance and mortality of a specialist leafminer in response to experimental shading and fertilization of American holly. Oecologia 91, 14-22. doi:10.1007/BF00317235

Powell, J.A., 2003. Lepidoptera. In: Resh, V.H. \& Cardé, R.T. (ed) Encyclopaedia of insects. Academic Press, London. pp. $631-664$.

Price, P.W., Fernandes, G.W. \& Waring, G.L., 1987. Adaptive nature of insect galls. Environ. Entomol. 16, 15-24. doi:10.1093/ee/16.1.15

Progar, R.A., Kruse, J.J., Lundquist, J.E., Zogas. K.P. \& Rinella, M.J., 2014 An entomopathogenic fungus and nematode prove ineffective for biocontrol on an invasive leaf miner Profenusa thomsoni in Alaska. Biocontrol Sci. Techn. 25, 373-382. doi:10.1080/09583157.2014.977224

Regier, J.C., Mitter, C., Kristensen, N.P., Davis, D.R., Van Nieukerken, E.J., Rota, J., Simonsen, T.J., Mitter, K.T., Kawahara, A.Y., Yen, S.H., Cummings, M.P. \& Zwick, A., 2015. A molecular phylogeny for the oldest (nonditrysian) lineages of extant Lepidoptera, with implications for classification, comparative morphology and life-history evolution. Syst. Entomol. 40, 671-704. doi:10.1111/syen.12129

Roditakis, E., Steinbach, D., Moritz, G., Vasakis, E., Stavrakaki, M., Ilias, A., García-Vidal, L., Martínez-Aguirre, M.D., Bielza, P., Morou, E., Silva J.E., Silva, W.M., Siqueira, H.A.A., Iqbal, S., Troczka, B.J., Williamson, M.S., Bass, C., Tsagkarahou, A., Vontas, J. \& Nauen, R., 2017. Ryanodine receptor point mutations confer diamide insecticide resistance in tomato leafminer, Tuta absoluta (Lepidoptera: Gelechiidae). Insect Biochem. Mol Biol. 80, 11-20. doi:10.1016/j.ibmb.2016.11.003

Roditakis, E., Vasakis, E., García-Vidal, L., Martínez-Aguirre, M.D., Rison, J.L., Haxaire-Lutun, M.O., Nauen, R., Tsagkarakou, A. \& Bielza, P., 2018. A four-year survey on insecticide resistance and likelihood of chemical control failure for tomato leaf miner Tuta absoluta in the European/Asian region. J. Pest Sci. 91, 421-435. doi:10.1007/s10340-017-0900-X 
Rodríguez, S.M., Gerding, P.M. \& France, I.A., 2006. Entomopathogenic fungi isolates selection for egg control of tomato moth Tuta absoluta Meyrick (Lepidoptera: Gelechiidae) eggs. Agricultura Técnica 66, 151-158.

Schoeman, P.S., 2015. Coffee. In: Prinsloo, G.L. \& Uys, V.M. (eds). Insects of cultivated plants and natural pastures in southern Africa. Entomological Society of Southern Africa, Cape Town. pp. 530 - 541.

Scoble, M.J., 1992. The Lepidoptera: Form, function and diversity. Oxford University Press, New York.

Shah, P.A. \& Pell, J.K., 2003. Entomopathogenic fungi as biological control agents. Appl. Microbiol. Biotechnol. 61, 413-423. doi:10.1007/s00253-003$1240-8$

Shanower, T.G., Wightman, J.A. \& Gutierrez, A.P., 1993. Biology and control of the groundnut leafminer, Aproaerema modicella (Deventer) (Lepidoptera: Gelechiidae). Crop Prot. 12, 3-10. doi:10.1016/02612194(93)90014-A

Sharma, R.R., Reddy, S.V.R. \& Jhalegar, M.J., 2014. Pre-harvest fruit bagging: A useful approach for plant protection and improved post-harvest fruit quality - a review. J. Hortic. Sci. Biotechnol. 89, 101-113. doi:10.108 $0 / 14620316.2014 .11513055$

Signes, A.J., Burló, F., Martínez Sánchez, F. \& Carbonell-Barrachina, A.A., 2007. Effects of pre-harvest bagging on quality of black table grapes. World J. of Agric. Sci. 3, 32-38

Siqueira, H.A.A., Guedes, R.N.C. \& Picanço, M.C., 2001. Insecticide resistance in populations of Tuta absoluta (Lepidoptera: Gelechiidae). Agric. For. Entomol. 2, 147-153. doi:10.1046/j.1461-9563.2000.00062.x

Soper, A.L., Macquarrie, C.J.L. \& Van Criesche, R., 2015. Introduction, establishment, and impact of Lathrolestes thomsoni (Hymenoptera: Ichneumonidae) for biological control of the ambermarked birch leafminer, Profenusa thomsoni (Hymenoptera: Tenthredinidae), in Alaska. Biolog. Control 83, 13-19. doi:10.1016/j.biocontrol.2014.12.018

Spencer, K.A., 1973. Agromyzidae (Diptera) of economic importance. Series Entomologica, Volume 9. Dr W. Junk, The Hague, Netherlands.

Sporleder, M., Schaub, B., Aldana, G. \& Kroschel, J., 2017. Temperaturedependent phenology and growth potential of the Andean potato tuber moth, Symmetrischema tangolias (Gyen) (Lep., Gelechiidae). J. Appl. Entomol. 141, 201-218. doi:10.1111/jen.12321

Stehr, F.W., 1992. Lepidoptera. In: Immature insects. Kendall/Hunt Publishing Company, Iowa, United States.

Stelinski, L.L., Lapointe, S.L. \& Meyer, W.L., 2010. Season-long mating disruption of citrus leafminer, Phyllocnistis citrella Stainton, with an emulsified wax formulation of pheromone. J. Appl. Entomol. 134, 512-520. doi:10.1111/j.1439-0418.2009.01453.x

Stelinski, L.L., Miller, J.R. \& Rogers, M.E., 2008. Mating disruption of citrus leafminer mediated by a noncompetitive mechanism at a remarkably low pheromone release rate. J. Chem. Ecol. 34, 1107-1113. doi:10.1007/ s10886-008-9501-8

Steyn, L.A.I., Addison, P. \& Malan, A.P., 2019. Potential of South African entomopathegenic nematodes to control the leaf miner, Holocacista capensis (Lepidoptera: Heliozelidae). S. Afr. J. Enol. Vitic. 40, 301-307. doi: $10.21548 / 40-2-3420$

Stock, S.P., 2015. Diversity, biology and evolutionary relationships. In: Campos-Herrera, R. (ed). Nematode pathogenesis of insects and other pests. Springer International Publishing, Cham, Switzerland. pp. 3-27.

Stock, S.P. \& Hunt, D.J., 2005. Morphology and systematics of nematodes used in biocontrol. In: Grewal, P.S., Ehlers, R.-U. \& Shapiro-Ilan, D.I (eds). Nematodes as biocontrol agents. CABI Publishing, Wallingford, Oxfordshire. pp. $3-63$.
Suvočarev, K., Blanco, O., Faci, J.M., Medina, E.T. \& Martínez-Cob, A., 2013. Transpiration of table grape (Vitis vinifera L.) trained on an overhead trellis system under netting. Irrig. Sci. 31, 1289-1302. doi:10.1007/s00271013-0404-2

Torrance, L.A.I., 2016. The bio-ecology of the Cape grapevine leafminer, Holocacista capensis (Lepidoptera: Heliozelidae), in the Western Cape. Thesis, Stellenbosch University, Private Bag X1, 7602 Matieland (Stellenbosch), South Africa.

Trumble, J.T., 1985. Integrated pest management of Liriomyza trifolii: Influence of avermectin, cyromazine, and methomyl on leafminer ecology in celery. Agric. Ecosyst. Environ. 12, 181-188. doi:10.1016/01678809(85)90109-4

Ueno, W., Hayasaka, T., Endo, S. \& Shibahasi, T., 1987. Ecology and control of Antispila sp. (Lepidoptera: Heliozelidae) infesting grape leaves. Bull. Yamagata Prefectural Hortic. Exp. Station 6, 1-18

Ureche, C., 2016. First record of a new alien invasive species in Romania: Phyllocnistis vitegenella Clemens (Lepidoptera: Gracillariidae). Acta Oecol. Carpatica IX, 133-138.

Vacas, S., Alfaro, C., Primo, J. \& Navarro-Llopis, V., 2011. Studies on the development of a mating disruption system to control the tomato leafminer, Tuta absoluta Povolny (Lepidoptera: Gelechiidae). Pest Manag. Sci. 67, 1473-1480. doi:10.1002/ps.2202

Van Damme, V.M., Beck, B.K.E.G., Berckmoes, E., Moerkens, R., Wittemans, L., De Vis, R., Nuyttens, D., Casteels, H.F., Maes, M., Tirry, L. \& De Clercq, P., 2015. Efficacy of entomopathogenic nematodes against larvae of Tuta absoluta in the laboratory. Pest Manag. Sci. 72, 1702-1709. doi:10.1002/ps.4195

Van Nieukerken, E.J. \& Geertsema, H., 2015. A new leafminer on grapevine and Rhoicissus (Vitacea) in South Africa within an expanded generic concept of Holocacista (Insecta, Lepidoptera, Heliozelidae). ZooKeys 507, 41-97. doi:10.3897/zookeys.507.9536

Van Nieukerken, E.J., Kaila, L., Kitching, I.J., Kristensen, N.P., Lees, D.C., Minet, J., Mitter, C., Mutanen, M., Regier, J.C., Simonsen, T.J., Wahlberg, N., Yen, S.-H., Zahiri, R., Adamski, D., Baixeras, J., Bartsch, D., Bengtsson, B.Å., Brown, J.W., Bucheli, S.R., Davis, D.R., De Prins, J., De Prins, W., Epstein, M.E., Gentili-Poole, P., Gielis, C., Hättenschwiler, P., Hausmann, A., Holloway, J.D., Kallies, A., Karsholt, O., Kawahara, A.Y., Koster, S.J.C., Kozlov, M.V., Lafontaine, J.D., Lamas, G., Landry, J.-F., Lee, S., Nuss, M., Park, K.-T., Penz, C., Rota, J., Schintlmeister, A., Schmidt, B.C., Sohn, J.C., Solis, M.A., Tarmann, G.M., Warren, A.D., Weller, S., Yakovlev, R.V., Zolotuhin, V.M. \& Zwick, A., 2011. Order Lepidoptera Linnaeus, 1758. In: Zhang, Z.-Q. (ed). Animal biodiversity: An outline of higher-level classification and survey of taxonomic richness. Zootaxa 3148, 212-221.

Van Nieukerken, E.J., Wagner, D.L., Baldessari, M., Mazzon, L., Angeli, G., Girolami, V., Duso, C. \& Doorenweerd, C., 2012. Antispila oinophylla new species (Lepidoptera: Heliozelidae), a new North American grapevine leafminer invading Italian vineyards: Taxonomy, DNA barcodes and life cycle. ZooKeys 170, 29-77. doi:10.3897/zookeys.170.2617

Vári, L., 1961. South African Lepidoptera. Lithocolletidae, Transvaal Museum Memoir 12, Pretoria, South Africa.

Visser, D., 2015a. Sweet potato. In: Prinsloo, G.L. \& Uys, V.M. (eds). Insects of cultivated plants and natural pastures in southern Africa. Entomological Society of Southern Africa, Cape Town, South Africa. pp. $74-85$.

Visser, D., 2015b. Potato. In: Prinsloo, G.L. \& Uys, V.M. (eds). Insects of cultivated plants and natural pastures in southern Africa. Entomological Society of Southern Africa, Cape Town, South Africa. pp. 48 - 64.

Wang, H.-L., Geertsema, H., Van Nieukerken, E.J. \& Löfstedt, C., 2015. Identification of the female-produced sex pheromone of the leafminer Holocacista capensis infesting grapevine in South Africa. J. Chem. Ecol. 41, 724-731. doi:10.1007/s10886-015-0611-9 
Wei, J.N. \& Kang, L., 2006. Electrophysiological and behavioral responses of a parasitic wasp to plant volatiles induced by two leaf miner species. Chem. Senses 31, 467-477. doi:10.1093/chemse/bjj051

Weintraub, P.G. \& Horowitz, A.R., 1998. Effects of translaminar versus conventional insecticides on Liriomyza huidobrensis (Diptera:Agromyzidae) and Diglyphus isaea (Hymenoptera: Eulophidae) populations in celery. J. Econ. Entomol. 91, 1180-1185. doi:10.1093/jee/91.5.1180

Willett, D.S., Stelinski, L.L. \& Lapointe, S.L., 2015. Using response surface methods to explore and optimize mating disruption of the leafminer Phyllocnistis citrella (Lepidoptera: Gracillariidae). Front. Ecol. Evol. 3, 1-11. doi:10.3389/fevo.2015.00030
Williams, E.C. \& Walters, K.F.A., 2000. Foliar application of the entomopathogenic nematode Steinernema feltiae against leafminers on vegetables. Biocontrol Sci. Techn. 10, 61-70. doi:10.1080/09583150029396

Wright, M.G., 2015. Proteas. In: Prinsloo, G.L. \& Uys, V.M. (eds). Insects of cultivated plants and natural pastures in southern Africa. Entomological Society of Southern Africa, Cape Town, South Africa. pp. $680-695$ 